\title{
Riboflavin lowers blood pressure in hypertensive people with the MTHFR 677TT genotype
}

\author{
Helene McNulty", JJ Strain, Mary Ward \\ From Genes and nutrition, is personalised nutrition the next realistic step? \\ Brussels, Belgium. 25 April 2014
}

Hypertension, defined as a systolic/diastolic blood pressure of $140 / 90 \mathrm{mmHg}$ or greater, is estimated to carry a 3-fold increased risk of developing cardiovascular disease (CVD), while treating hypertension significantly reduces CVD events, and stroke in particular. Among the many risk factors involved, there is much recent interest in the role of genetic factors that might predispose to hypertension.

Evidence from genome-wide association studies has identified an association between blood pressure and the gene encoding the folate-metabolising enzyme, methylenetetrahydrofolate reductase (MTHFR), while recent meta-analyses of observational studies show an increased risk of hypertension in people homozygous for the $677 \mathrm{C} \rightarrow \mathrm{T}$ polymorphism in MTHFR. Riboflavin (vitamin B2) in the form of FAD acts as a cofactor for MTHFR and we have been studying its modulating role in relation to this polymorphism. The variant enzyme is known from molecular studies to become inactive as a result of having an increased propensity to dissociate from FAD, but our earlier work suggested that supplementation with low-dose riboflavin could stabilise MTHFR activity in vivo in homozygous individuals. In recent years we showed that CVD patients with the relevant MTHFR 677TT genotype (compared to CC or CT genotypes) had significantly higher blood pressure, and that blood pressure was highly responsive to riboflavin intervention, specifically in the TT genotype group [1]. Further investigations confirmed this gene-nutrient interaction in hypertensive patients (with and without overt CVD), and furthermore showed that the blood pressure lowering effect of riboflavin in the TT genotype group was independent of the number and type of antihypertensive drugs that they were taking [2].

\footnotetext{
* Correspondence: h.mcnulty@ulster.ac.uk

Northern Ireland Centre for Food \& Health, University of Ulster, Coleraine, BT52 1SA, UK
}

\section{and take full advantage of:}

- Convenient online submission

- Thorough peer review

- No space constraints or color figure charges

- Immediate publication on acceptance

- Inclusion in PubMed, CAS, Scopus and Google Scholar

- Research which is freely available for redistribution Submit your manuscript at
www.biomedcentral.com/submit C BioMed Central 